\title{
BRAZILIAN AGRIBUSINESS FACING AFRICAN FOOD INSECURITY
}

\author{
Eduardo Botti Abbade \\ Homero Dewes**
}

ABSTRACT: Brazilian agriculture has achieved high production levels in recent years. In contrast, agricultural production in Africa is low, but it shows great potential. This paper discusses the agricultural profiles of the main regions of Africa as well as the agribusiness partnership established between Africa and Brazil. This research is based on descriptive analysis of data collected in official agencies, such as FAO, the World Bank, the United Nations, and the Africa-Brazil Institute. This study points collaborative projects currently active in the agribusiness partnership between Africa and Brazil. Several active collaborative projects are located in Western and Eastern Africa, which are problematic and unstable regions. We argue that Brazil can help African development through a sharp focus on both elementary and emancipatory projects. Thus, attention to Middle Africa should focus on political and conflict instabilities, since these problems might prevent a collaborative partnership with the Brazilian agribusiness sector. The main limitation of this study is that it is based on vague data obtained in official agencies. Another limitation is the absence of details about the active projects. This paper is an important contribution to the literature regarding food security, political instability, and economic development in Africa. It suggests the need for a better alignment between political and private efforts focused on the alleviation of urgent problems.

KEY WORDS: Agriculture; African Development; Emerging Economies; Agricultural Efficiency; Food Security.

\section{O AGRONEGÓCIO BRASILEIRO FRENTE À INSEGURANÇA ALIMENTAR AFRICANA}

RESUMO: A agricultura brasileira tem alcançado altos níveis de produção nos últimos anos. Em contraste, a produção agrícola na África é ainda baixa, mas mostra

\footnotetext{
"Doutor em Agronegócios Universidade Federal do Rio Grande do Sul (UFRGS); Docente Adjunto do Centro Universitário Franciscano (UNIFRA), Santa Maria (RS), Brasil; E-mail: eduardo@unifra.br

${ }^{* *}$ Doutor em Biologia pela University of California Los Angeles; Docente titular do Departamento de Biofísica da Universidade Federal do Rio Grande do Sul Federal (UFRGS), Brasil.
} 
grande potencial. Este artigo apresenta os perfis agrícolas das principais regiões da África, bem como a parceria de agronegócio estabelecidas entre a África e o Brasil. Esta pesquisa é baseada em análise descritiva de dados coletados em órgãos oficiais, como a FAO, o Banco Mundial, Nações Unidas e o Instituto África-Brasil. Este estudo aponta os projetos colaborativos atualmente ativos na parceria de agronegócio entre a África e o Brasil. Vários projetos de colaboração estão localizados no Oeste e no Leste da África, que são regiões problemáticas e instáveis. Argumentamos que o Brasil pode auxiliar o desenvolvimento africano através de um forte foco em projetos básicos e emancipatórios. Assim, a atenção dada à África central deve ser concentrada em instabilidades políticas e conflitos, uma vez que estes problemas podem impedir o avanço da parceria de colaboração com o setor do agronegócio brasileiro. A principal limitação deste estudo é que ele é baseado em dados vagos obtidos em agências oficiais. Outra limitação é a ausência de detalhes sobre os projetos ativos. Este estudo é uma contribuição importante sobre a segurança alimentar, a instabilidade política e desenvolvimento econômico na África. Salientase, ainda, a necessidade de um melhor alinhamento entre os esforços políticos e privados voltados para o alívio de problemas urgentes, como a fome e a desnutrição infantil.

PALAVRAS-CHAVE: Agricultura; Desenvolvimento Africano; Economias Emergentes; Eficiência Agrícola; Segurança Alimentar.

\section{INTRODUCTION}

\subsection{OBJECTIVE}

In recent decades, the Brazilian agribusiness sector has sharply improved its capabilities and performance. In contrast, the African continent, although it has vast tracts of land with great potential for agribusiness activities, requires attention to its agricultural practices and performance. This study aims first to describe the evolution of the main regions of Africa regarding their agricultural yield and main agricultural factors. Second, we discuss the nature of the cooperative relationship between Brazil and Africa in order to help the African continent to enhance economic development and agricultural innovation (AFRICA-BRAZIL.ORG, 2013). Thus, this paper also argues that, considering the urgent situation of undernourishment and 
food insecurity in Africa, the initiatives and projects established in partnership with Brazil should target these as major problems. In addition, we present empirical evidence of some potential barriers and limitations to this partnership. Furthermore, this study intend to present a practical contribution that could promote a better understanding about this partnership, which would allow the promotion of initiatives and projects specifically focused on higher food production and economic development. In addition, we present empirical evidence of some potential barriers and limitations to this partnership.

\subsection{BACKGROUND}

The production of sufficient quantities of food is one of the most important challenges of humanity because of the need for food security in the world (GODFRAY et al., 2010). In addition, as a global goal, food security is defined as sufficient food acquisition in terms of quantity and nutritional elements (SEN, 1981; FAO, 2013). Thus, agricultural activities and improvement have important social implications. Moreover, because agriculture activity has a high economic impact, developing countries take advantage of their agricultural potential and natural resources to maintain sustainable economic growth. In 2009, the total amount of arable land in the world was estimated at 1.38 billion hectares, $5.41 \%$ and $23.75 \%$ of which are in Brazil and Africa, respectively (FAO, 2015).

Brazil is currently seen as one of the greatest "barns" of the world (THE ECONOMIST, 2010), with potential for the production of food for worldwide distribution (CONTINI; MARTHA, 2010). Brazil holds a prominent position in the production of many foods, such as sugar cane, orange, green coffee, papaya, drybeans, soybeans, cattle and chicken meats, and pineapple. Brazilian exports also have international prominence. In 2012, the country was the world's largest exporter of sugar (raw centrifuged), chicken meat, coffee, and orange juice. It was also the second largest exporter of soybeans and soybean cake (FAO, 2015). Thus, Brazil has a prominence position as a great world exporter of meats and meat products, and corn. On the other hand, Brazil is also an important importer of wheat, maize, and dry-beans (FAO, 2015), which are important staple foods of the Brazilian diet. 
Brazilian agribusiness is an important driver of the country's economic growth. However, authors argue that this economic development based on agricultural exploration had significant impacts on Brazilian ecosystem, and also aggravated social inequality (MARTINELLI et al., 2010). Nevertheless, the Brazilian agribusiness sector still has great potential for economic exploitation.

Africa also has a high potential for food production, and its agricultural activities have attracted the attention of the world. With its wide range of arable land, Africa has important advantages, such as climatic conditions and low labor costs. On the other hand, politics (OLUKOSHI, 2006), land control (CONNOLLY; CONNOLLY; LYON, 2012) and the movement of the population to urban areas (VAN ROOYEN; SIGWELE, 1998; HAGGBLADE, 2011) represent great challenges to agricultural activities on the African continent. Previous studies suggested that the poor performance of agriculture in Africa is caused by inadequate investment and policies in the agricultural sector (FAN; ZHANG; RAO, 2004; TIMMER, 2005). Small farm sizes, poor access to knowledge and support services, low investments in infrastructure, and weak irrigation schemes have also limited agricultural development in Sub-Saharan Africa (FAURÈS; SANTINI, 2008). Considering the fact that the African continent has a significant portion of the world's hungry and undernourished population (FAO, 2013; WFP, 2011), the development of its agricultural potential can alleviate food insecurity in not only African countries but also the rest of the world. Therefore, the partnership established between Brazil and Africa to develop their agribusiness sectors is strategic in its possible positive effects on the entire world. Therefore, active projects should be investigated to determine their focus on urgent issues, such as 1) fighting hunger and poverty; 2) the empowerment of African societies and small farms; and 3) sustainable economic development.

\subsection{METHOD}

The present study is based on descriptive analysis of data related to agricultural activities and partnership projects established between Brazil and Africa. Brazil and Africa are developing some important initiatives in order to enhance 
their agricultural activities. Thus, Brazil and Africa have similar conditions regarding geography and climatic conditions. So, Brazil can serve as a good example to African initiatives. It focuses on the agricultural evolution of the main regions of Africa and compares the urgency of agricultural improvement and the concentration levels of projects in partnership with Brazil. The comparison of the main regions of Africa was designed to consider specific issues, such as harvest areas, agriculture yield, fertilizer consumption, and capital investment in agriculture. The data for these four variables in agricultural activities were obtained from the Food and Agriculture Organization of the United Nations (2012). In this study, these four variables concern the period between 1975 and 2010. The subdivision of the five regions in Africa is based on the classifications provided by the Food and Agriculture Organization (2012). Although different classifications are available, but this study adopted the classifications suggested by the Food and Agriculture Organization because they suit the objectives of this study and thus are convenient for the researcher.

\section{AGRICULTURE IN AFRICA}

The first analysis provides a comparison of the historical evolution of the harvest area of cereals, fruits, legumes, roots, tubers, and vegetables grown in African regions (Figure 1). Evidence indicates that the West African region has the largest amount of harvest areas of the above crops. Thus, in the present study, harvest areas in Western Africa have sharply increased since the early 1980s. In comparison, in other regions production has been stationary. The African region with the lowest amount of harvest area is Southern Africa. 


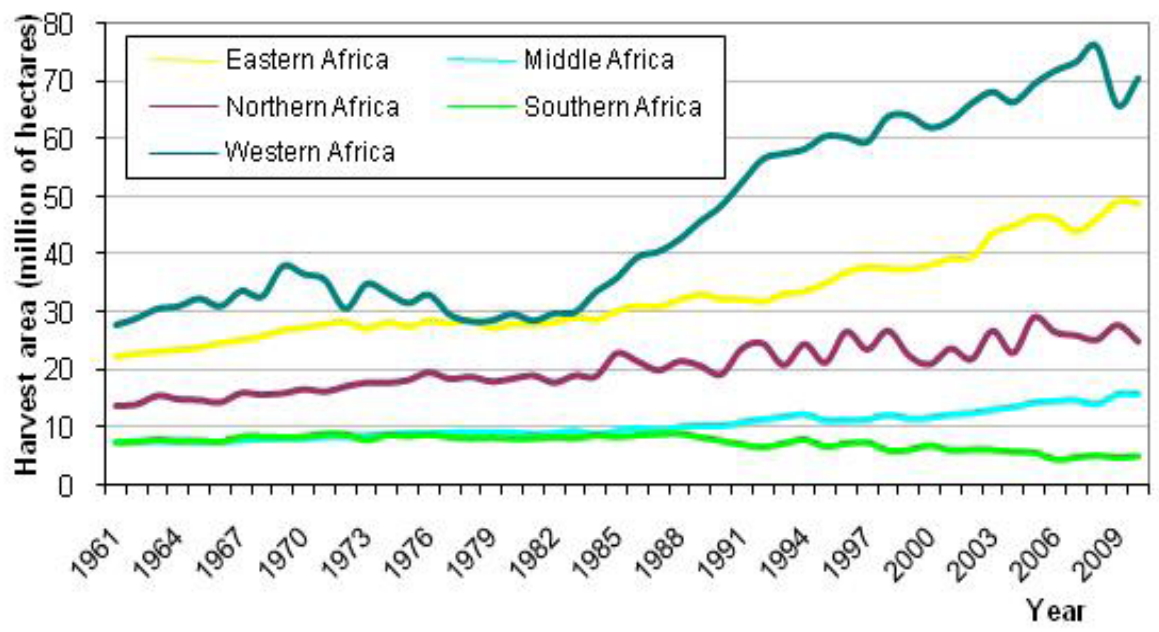

Figure 1. Harvest area*

Note: * Cereals, fruits, pulses, roots, tubers and vegetables.

Source: Food and Agriculture Organization (2012).

Regarding the evolution of harvest areas, Eastern Africa has also experienced strong growth, having doubled its harvest area between 1961 and 2009. This increase suggests that this region has aimed to improve its agricultural activities dramatically. This argument might be reinforced by evidence of the evolution of agricultural productivity, or yield (Figure 2).

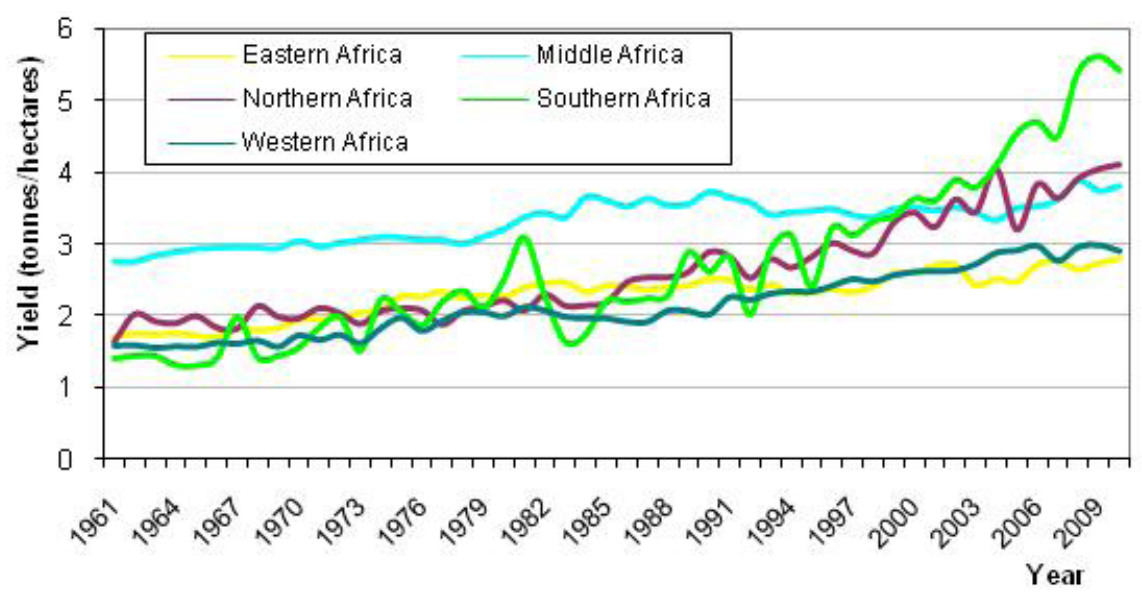

Figure 2. Agricultural productivity*

Note: * Cereals, fruits, pulses, roots, tubers and vegetables.

Source: Food and Agriculture Organization (2012). 
The agricultural productivity presented in Figure 2 is focused on the agricultural yields of cereals, fruits, pulses, roots, tubers, and vegetables crops. The Eastern and Western regions of Africa have the least agricultural productivity. However, these regions have the greatest amount of harvest areas, which may suggest that because low productivity, the amount of area used for agriculture should be increased in order to achieve sufficient and satisfactory agricultural production. However, low productivity may also indicate that these regions do not use agricultural technology to grow their crops. Middle and Northern Africa show intermediate levels of agricultural productivity. Despite the great extension of the desert area in Northern Africa, its productivity is higher than in other areas of Africa, which have better and more suitable climatic conditions for agriculture. Another indicator that helps to evaluate the adoption of efficiency and technology in agriculture is the amount of fertilizer consumed in each main region of Africa (Figure 3).

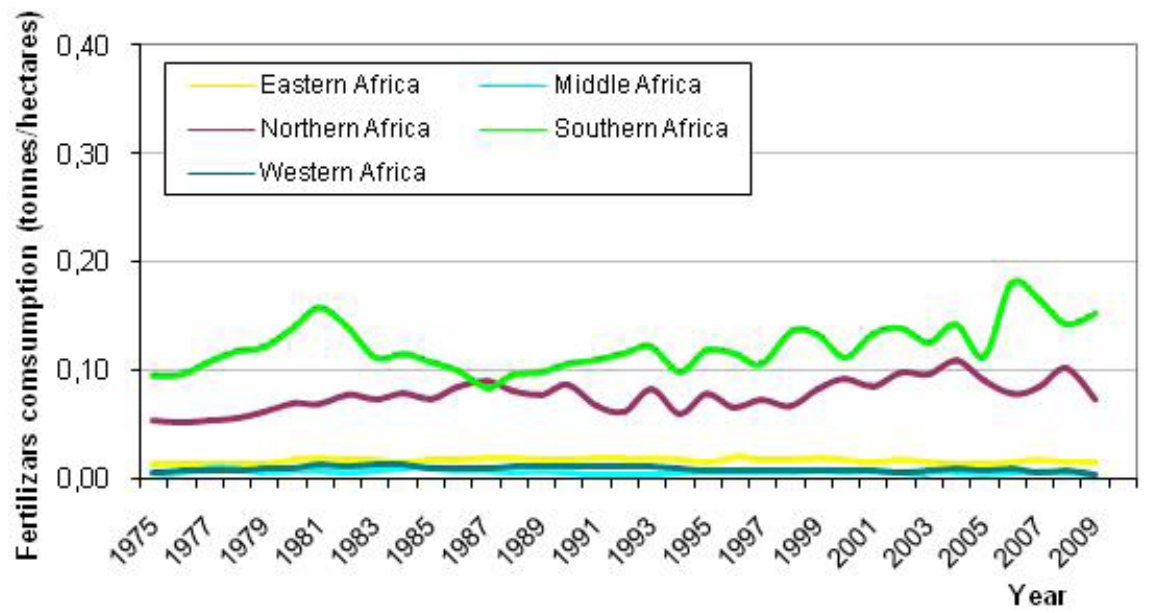

Figure 3. Fertilizer consumption* (tonnes / harvest area) Note: * Cereals, fruits, pulses, roots, tubers and vegetables crops. Source: Food and Agriculture Organization (2012).

Evidence indicates that the regions of Southern and Northern Africa have the greatest consumption of fertilizer per hectare. On the other hand, the fertilizer consumption in Western, Eastern, and Middle Africa is negligible. The greater consumption of fertilizers in Northern Africa could be associated with a 
sharper technological investments and unfavorable climatic conditions, which is a plausible explanation for its moderate agricultural productivity. However, Eastern and Western Africa, which are regions with lower agricultural productivity, do not consume significant amounts of fertilizer, which probably affects their agricultural performance. Evidence suggests that a possible way of improving the agricultural productivity in these regions could be by the more efficient use of fertilizers. Moreover, the evolution of capital investments is seen as an important variable in agricultural production (Figure 4).

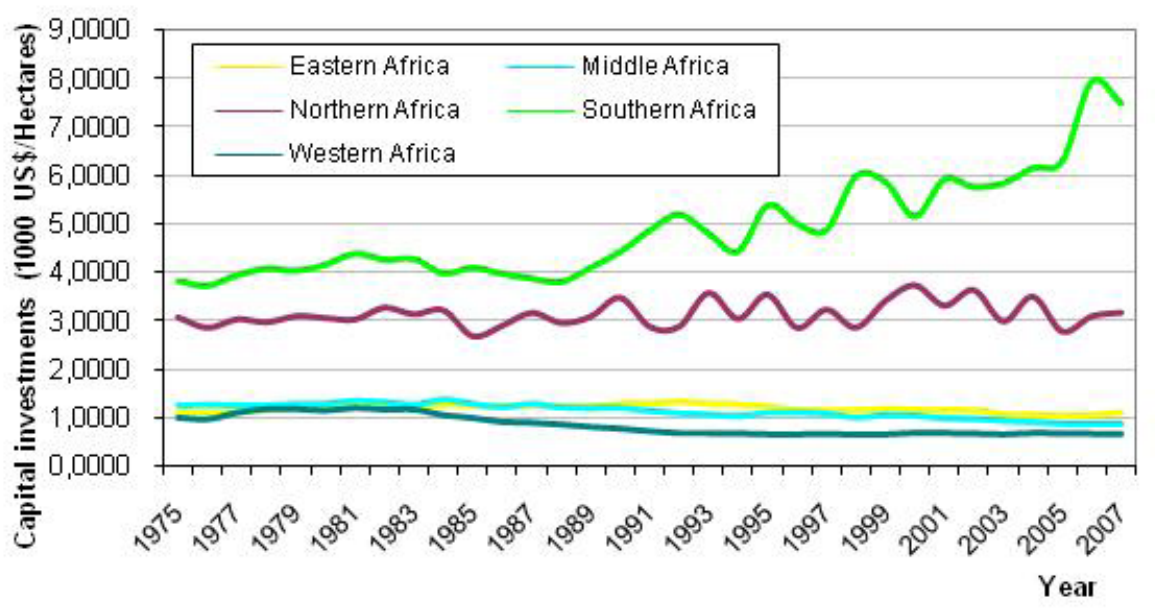

Figure 4. Capital investments ** (US\$ / harvest area*)

Note: * Cereals, fruits, pulses, roots, tubers and vegetables. ** Investments in land development, machinery, equipment, and plantation crops with US\$ in 2005 as constant.

Source: Food and Agriculture Organization (2012).

Another factor contributing to the agricultural development considered in this study is the amount of capital investment per hectare of harvest area. Evidence shows that Southern Africa has the largest capital investments in agriculture, Northern Africa has moderate amounts of capital investments in agriculture, and Eastern, Western, and Middle Africa have the lowest amounts of capital investments in agriculture. These evidences related to productivity and fertilizer consumption show that the regions of Eastern and Western Africa have low capital investments, low use of fertilizers, and low agricultural productivity. This evidence suggests 
that these regions have the weakest agricultural profiles, in terms of the variables investigated in this study.

\section{THE AGRIBUSINESS PARTNERSHIP BET WEEN BRAZIL AND AFRICA}

Brazil is currently recognized as one of the major food producers in the world (CONTINI; MARTHA, 2010; THE ECONOMIST, 2010). This position in world food production has been achieved only recently because of domestic changes. Despite the increase in food production in Brazil, the country still has great potential for exploitation. In less than 30 years, Brazil has reversed its position as an importer of food to one of the most important "barns" of the world. Brazil is considered the first country to achieve levels of productivity and exports on par with the traditional "Big Five" (i.e., the five largest grain exporters, which are USA, Canada, Australia, Argentina, and the European Union). Between 1996 and 2006, the total value of crops in Brazil increased from $\mathrm{R} \$ 23$ billion to $\mathrm{R} \$ 108$ billion, representing an increase of 365\% (THE ECONOMIST, 2010). Brazil increased its exports of meat, overtaking Australia to assume the position of the largest exporter of meat in the world. Since 1990, Brazilian soybean production has increased from around 15 million tonnes to over 60 million tonnes. Brazil is the second largest exporter of soybeans and is responsible for about one third of the world's exports of soybeans (FAO, 2015).

In recent decades, Brazil has shown strong growth in its Gross Domestic Product (GDP). In 2012, with $\$ 2.3$ trillion dollars, Brazil was seventh among the highest GDPs in the world (INTERNATIONAL MONETARY FUND, 2012). Evidence indicates that gross investment has been mainly responsible for the growth in the Brazilian GDP in recent years (FERREIRA; MALLIAGROS, 1998; BONELLI; FONSECA, 1998; GOMES; PESSÔA; VELOSO, 2003). These investments had positive effects on agricultural activities in the country and thus increased its food productivity. Regarding Brazilian agricultural development, the focus has been on the introduction of new technologies, fertilizers, and pesticides to increase productivity (RODRIGUEZ, 2006). The excellent performance of Brazil can also be attributed to a series of reforms in agricultural policy promoted by the government, especially 
regarding agricultural exports (YAN; YI-XIANG; YI, 2009). Among the factors that have led Brazil to a prominent position in food production are the following: 1) industrialization and migration of population from rural to urban areas; 2 ) subsidized financial credit, primarily capital finance and to acquire modern agricultural inputs; 3) extension activities; and (4) support for agricultural research under the leadership of the Brazilian Agricultural Research Corporation (EMBRAPA) (CONTINI; MARTHA, 2010). However, Brazil still have significant challenges ahead.

In Africa, agribusiness has the great potential for exploitation in future decades. Furthermore, the growth in African agro-industrial productivity will dramatically affect the growth rate of Africa in wide socio-economic and environmental terms and its initiatives to reduce poverty. However, the efficiency necessary to improve Africa's performance will depend on the focus of African agribusiness activities on fostering private investment, promoting regional trade, improving urban and regional planning, and funding scientific research (HAGGBLADE, 2011).

Furthermore, improvements in agriculture and food production in Africa have the potential to alleviate hunger and malnutrition worldwide. However, despite this potential, in their fight against hunger and malnutrition, some African regions are the most affected by food insecurity and lower performance levels. Several African countries, such as the Democratic Republic of Congo, Somalia, Zambia, Uganda, United Republic of Tanzania, and Botswana have shown no progress in combating hunger and some have increased numbers of hungry and undernourished people (FAO, 2010). In addition, in ten African nations (i.e., Chad, Angola, Zambia, Democratic Republic of Congo, Mozambique, Ethiopia, Central African Republic, Eritrea, Burundi, and Sierra Leona) large percentages of the population are (more than 35\%) undernourished (WFP, 2011). Furthermore, some of these nations have shown dire weaknesses in their logistics performance (WORLD BANK, 2013) and alarming levels of political instability and conflict (GLOBAL OBSERVATORY, 2013). Such evidence could explain the weak agricultural and economic development in these regions.

Evidence has shown that in Southern African, a great part of the population, which is mainly concentrated in rural areas, faces urgent problems of food insecurity and poverty. This condition is intensified by adverse weather conditions, which 
negatively affect food production. Nevertheless, agriculture is a primary economic activity in this region. Logically, the achievement of sustainable agriculture in Africa has a key role in promoting food security. Another issue is urbanization, which is expected to increase dramatically in the coming decades. The provision of nutritional conditions and food security to large urban populations should be given high priority (VAN ROOYEN; SIGWELE, 1998).

A study conducted in Morocco, Algeria and Tunisia (BENJELLOUN, 2004) found that the agricultural activities of these countries play an important role in their GDP. However, these three countries have serious problems in food security. Imports of cereals and sugar are very high, and milk production in the region is far from the recommended nutritional intake in these three countries (BENJELLOUN, 2004), which suggests trade opportunities. Therefore, investment in the African agricultural sector (e.g., Sub-Saharan Africa) is required for the reduction of poverty and food insecurity (MWABU; THORBECKE, 2004).

Considering the political debate about agricultural and economic development in Africa, market liberalization, and the promotion of private property, higher agricultural productivity and the desired economic growth have not been achieved. Furthermore, these policies have accelerated new forms of inequality that manifest through a dual process of land concentration and the dispossession of communities and individuals (OLUKOSHI, 2006). Consequently, the political debate faces elementary issues regarding the structured development of agricultural production. Thus, initiatives are needed concerning the effects of agribusiness on economic development, particularly with regard to African societies and environments.

Accordingly, Brazil and Africa have established an innovative partnership to boost agriculture in sub-Saharan Africa, based on the agricultural model used in Brazil. This initiative is called the "Africa-Brazil Agricultural Innovation Marketplace" and is primarily intended to benefit small producers. The core objective is to promote innovation in the development of agriculture on the African continent. This should be accomplished through creating and strengthening partnerships between African and Brazilian organizations, promoting research and agricultural development in Africa and Brazil (initially through EMBRAPA), and by supporting small producers.

Some projects have already been implemented, some of which are focused 
on specific regions in Africa, such as Burkina Faso, Kenya, Mozambique, Tanzania, and Togo. Furthermore, these projects are aimed at ameliorating important issues, such as food security, production of ethanol, and water use (WORLD BANK, 2010; AFRICA-BRAZIL.ORG, 2012). Figure 5 shows the location of these active projects on the African continent.

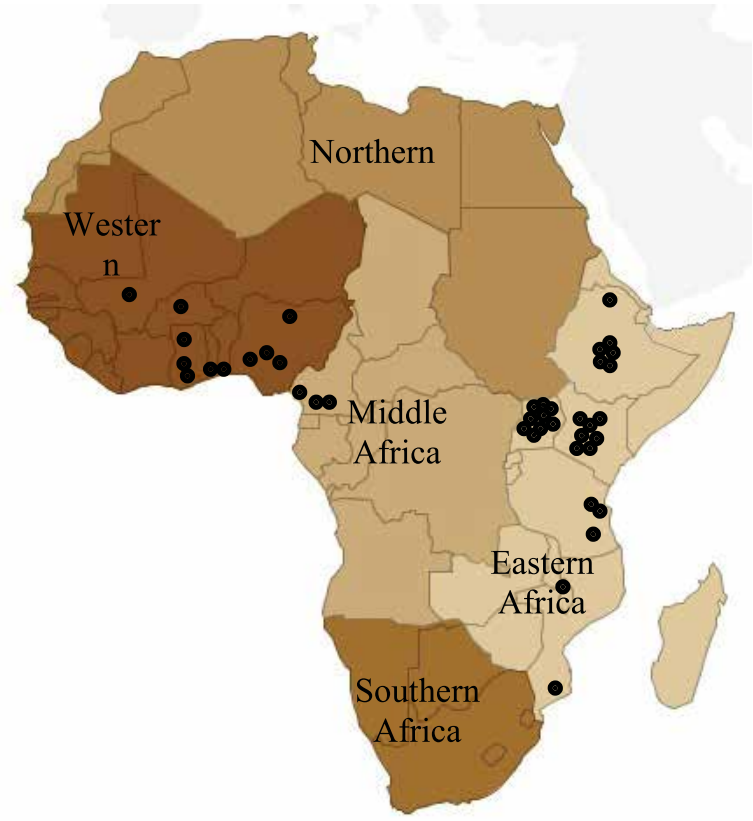

Figure 5. Main regions of Africa and active projects (partnership with EMBRAPA).

Source: Based on the classification of FAO (2015) and data from Africa-Brazil.org (2015).

As Figure 5 shows, the active projects are concentrated in Western and Eastern Africa. These regions are considered poor in terms of agricultural development (e.g., fertilizer consumption, agricultural yield, and capital investments) and economic development. Moreover, the projects include a series of efforts and concerns regarding the development of agricultural production and the number of small producers. In addition, some projects are focused on issues related to the social and environmental concerns of the poorest regions of Africa. A list of projects currently being implemented is presented in Table 1 . 
Table 1. List of projects (40) being implemented in the African continent

(continua)

\begin{tabular}{|c|c|c|}
\hline Country & \multicolumn{2}{|l|}{ Project Title } \\
\hline Benin & Production and management options for improved smallholder goat profitability & O \\
\hline $\begin{array}{l}\text { Burkina } \\
\text { Faso }\end{array}$ & $\begin{array}{l}\text { Study of the Ecology and Nutritional Potential of Native Food Tree Species used } \\
\text { by local communities in Burkina Faso and Brazilian Amazon: A Food security and } \\
\text { conservation strategy in the context of climate change }\end{array}$ & 0 \\
\hline \multirow{3}{*}{ Cameroon } & Swidden Systems for Poverty Alleviation and Provision of Environmental Services & 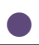 \\
\hline & Coffee genetic diversity in relation to drought tolerance (COFDROnet) & O \\
\hline & $\begin{array}{l}\text { Development and sustainable breeding of local chicken for improved } \\
\text { productivity under local alternative feed management system and health control }\end{array}$ & \\
\hline \multirow{6}{*}{ Ethiopia } & $\begin{array}{l}\text { Introduction of Napier grass elite lines for screening for stunt resistance to } \\
\text { provide feed for improved smallholder dairy productivity }\end{array}$ & ○ \\
\hline & $\begin{array}{l}\text { Swine Improvement in Ethiopia through Genetic and Socio-Economic } \\
\text { Characterization and Development of a Production System }\end{array}$ & \\
\hline & $\begin{array}{l}\text { Improving livelihoods of smallholders through implementation of sustainable } \\
\text { small ruminant improvement programs }\end{array}$ & \\
\hline & Bee Diversity And Crop Pollination For Food Security & \\
\hline & $\begin{array}{l}\text { Narrowing the yield gap of food legumes through integrated management of } \\
\text { parasitic weeds in the highlands of Ethiopia }\end{array}$ & \\
\hline & $\begin{array}{l}\text { Improving crop productivity through use of efficient, low cost and climate smart } \\
\text { irrigation technologies }\end{array}$ & \\
\hline \multirow{3}{*}{ Ghana } & Enhancing small-holder cowpea legume production using rhizobium inoculants & 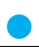 \\
\hline & $\begin{array}{l}\text { Characterization, conservation and domestication of indigenous edible and } \\
\text { medicinal mushrooms on agricultural residues }\end{array}$ & \\
\hline & Comparative evaluation of different manual cassava harvesting tools & 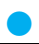 \\
\hline \multirow{7}{*}{ Kenya } & $\begin{array}{l}\text { Rehabilitation of degraded rangeland using planned grazing and animal impact } \\
\text { in the arid and semi-arid lands of Kenya }\end{array}$ & \\
\hline & Facilitating local level dairy innovation platforms for smallholder farmers & \\
\hline & $\begin{array}{l}\text { Fostering knowledge sharing for integrated natural resource management in } \\
\text { agricultural landscapes of Southern Africa }\end{array}$ & \\
\hline & $\begin{array}{l}\text { Application of DNA-markers for development of drought tolerant potato } \\
\text { germplasm }\end{array}$ & \\
\hline & $\begin{array}{l}\text { Developing a push-pull IPM strategy for smallholder cotton for Female in Africa } \\
\text { and Northeast of Brazil }\end{array}$ & \\
\hline & Sweet sorghum varietal adaptation for ethanol production & \\
\hline & $\begin{array}{l}\text { Confidence-Building in Modern Biotechnology: Optimizing Best Communication } \\
\text { Practices and Policies to Guide Deployment of Biotech/GM crops in Africa and } \\
\text { Brazil }\end{array}$ & \\
\hline Malawi & $\begin{array}{l}\text { Enhancing Crop Productivity through Solar-Powered Groundwater Based Drip } \\
\text { Irrigation System in Malawi. }\end{array}$ & \\
\hline
\end{tabular}


(conclusão)

\begin{tabular}{|c|c|c|}
\hline Country & \multicolumn{2}{|l|}{ Project Title } \\
\hline Mali & $\begin{array}{l}\text { Enhancing rice and maize production by small-holders using bacteria-plant } \\
\text { extract biopesticide }\end{array}$ & ○ \\
\hline Mozambique & $\begin{array}{l}\text { Sustainable Rice Production Intensification in Conservation Agriculture: } \\
\text { Incorporation of Legume and Grass as Cover Crops for Weed Management and } \\
\text { Soil Health Enhancement }\end{array}$ & - \\
\hline \multirow{4}{*}{ Nigeria } & $\begin{array}{l}\text { Participatory Evaluation and Promotion of Improved Pepper Cultivars (Capsicum } \\
\text { Spp) Among Small Holder Farmers }\end{array}$ & - \\
\hline & Nutritional properties and health functionality of wholegrain millet sourdoughs & - \\
\hline & Generation of virus resistant cowpea & - \\
\hline & $\begin{array}{l}\text { Comprehensive Molecular Genetic Characterization Among West Africa and } \\
\text { Brazil Locally Adapted Poultry Breeds: Creation of a Basis for Germplasm } \\
\text { Exchange }\end{array}$ & - \\
\hline \multirow{3}{*}{ Tanzania } & $\begin{array}{l}\text { Species identification of root-knot nematodes (RKN) through improved } \\
\text { diagnostic techniques aimed at durable resistance in vegetables grown in peri- } \\
\text { urban systems in Africa }\end{array}$ & ○ \\
\hline & Cotton varieties and pest management in Tanzania & O \\
\hline & $\begin{array}{l}\text { Exchange of banana and plantain (Musa spp.) varieties and hybrids between IITA } \\
\text { and EMBRAPA - widening the genetic base for the development of new cultivars } \\
\text { and direct use by farmers }\end{array}$ & ○ \\
\hline Togo & Pesticide leaching and loss to groundwater in coastal vegetable growers in Togo & - \\
\hline \multirow{8}{*}{ Uganda } & $\begin{array}{l}\text { Evaluation of anti-tick vaccine technology for adoption in strategic control of } \\
\text { ticks and tick-borne diseases in Uganda }\end{array}$ & - \\
\hline & $\begin{array}{l}\text { Enhancing Cowpea Production And Nutrition Through Developing Drought } \\
\text { Tolerant And High Protein Lines }\end{array}$ & • \\
\hline & $\begin{array}{l}\text { Validation of molecular-assisted selection for cassava mosaic disease and } \\
\text { screening of cassava wild relatives as resistance sources for cassava brown streak } \\
\text { virus }\end{array}$ & • \\
\hline & $\begin{array}{l}\text { Identification of broad resistance sources to anthracnose and rust in common } \\
\text { bean and resistance gene tagging using SNP markers }\end{array}$ & - \\
\hline & Utilization of Hydraulic Ram Pumps for promoting small-scale Irrigation & O \\
\hline & $\begin{array}{l}\text { Utilizing Sustainable Energy for Water Management in Semi-intensive } \\
\text { Aquaculture }\end{array}$ & ○ \\
\hline & $\begin{array}{l}\text { Towards genetic improvement of farmer preferred rice varieties to the stalk-eyed } \\
\text { fly (Diopsis sp): an emerging pest in rainfed irrigated rice growing ecosystems }\end{array}$ & - \\
\hline & $\begin{array}{l}\text { Inoculation of efficient rhizobial strains as an approach to increase the } \\
\text { pigeonpea production of smallholders in Uganda. }\end{array}$ & - \\
\hline
\end{tabular}

Note: Natural Resource Management Improvement; Policy, Institutional and Market Strengthening and Knowledge Management; $\bigcirc$ Productivity Enhancing Technologies; Smallholder and Poverty-Alleviation Targeted Technologies.

Source: Adapted from Africa-Brazil.org (2015). 
As Table 1 indicates, the greatest number of agribusiness projects is in the categories of productivity and technology. Thus, a strong focus is on the development of smallholders. Evidence suggests that the positive impact of agricultural growth on rural development is stronger in nations where agricultural activities are dominated by small farms (ROSEGRANT; HAZELL, 2000). Furthermore, projects with heterogeneous goals are located mostly in Western and Eastern Africa. This can be related to the fact that the economic conditions facing low-income African countries are widespread (DIAO, HAZELL; THURLOW, 2010). Moreover, the possible barriers imposed by the conflict levels and political instability in some African nations (Figure 6) could explain the lack of active projects in Middle Africa.
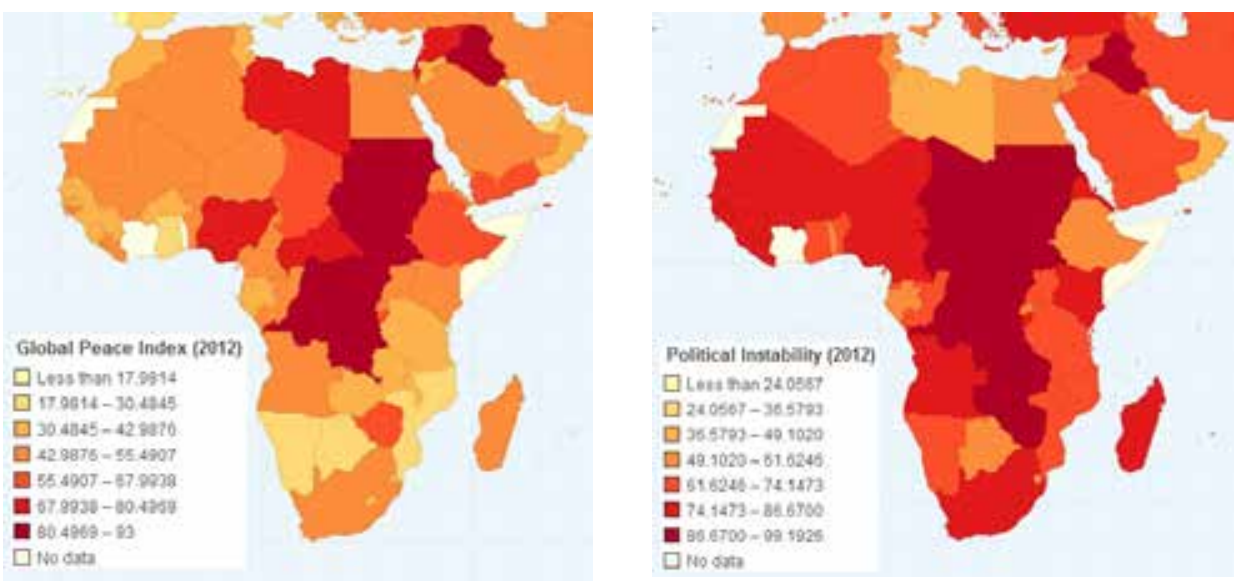

Figure 6. Global Peace Index and political instability in Africa Source: International Peace Institute (2012).

As Figure 6 shows, Middle Africa indicates lower levels of the Global Peace Index as well as high levels of political instability (INTERNATIONAL PEACE INSTITUTE, 2013). The negative profile of some African nations might impose strong barriers to the establishment of projects that are focused on the improvement of their agricultural activities. Furthermore, the level conflict can discourage foreign nations from sending specialist teams to develop agribusiness in such regions. Political instability urgently requires attention in Africa (VAN DIJK, 2008) in order to develop its agricultural sector. Thus, political instability and hunger in African 
continent are related issues (KITISSOU, 2014). Indeed, food security in Africa is an issue that has already addressed considering political aspects like trade liberalization strategies (CHIKHURI, 2013) and political leadership (DIRIYE, NUR; KHALIF, 2013; MWICHABE, 2013) in order to enhance African agricultural development. The profile of 13 African countries that have active projects in partnership with Brazil (Table 2) shows that agriculture can assist economic development and poverty reduction in these nations.

Table 2. Profile of African countries with active projects

\begin{tabular}{lccccccc}
\hline Countries & $\begin{array}{c}\text { Rural } \\
\text { pop. } \\
(\%)\end{array}$ & $\begin{array}{c}\text { HDI } \\
(2012)\end{array}$ & $\begin{array}{c}\text { Undernourished } \\
\text { pop. (\%) (2011) }\end{array}$ & $\begin{array}{c}\text { GDP per } \\
\text { capita } \\
\text { US\$ } \\
(2011)\end{array}$ & $\begin{array}{c}\text { Balance of } \\
\text { Trade } \\
\text { (million } \$(2009)\end{array}$ & $\begin{array}{c}\text { Cultivated } \\
\text { area (\%) } \\
(2011)\end{array}$ & $\begin{array}{c}\text { Permanent } \\
\text { Pasture } \\
\text { area (\%) } \\
(2011)\end{array}$ \\
\hline Benin (1) & 54.43 & 0.436 & 8.1 & 802 & $-1,123.62$ & 25.54 & 4.88 \\
\hline $\begin{array}{l}\text { Burkina Faso } \\
\text { (1) }\end{array}$ & 72.65 & 0.343 & 25.9 & 595 & $-1,074.74$ & 21.07 & 21.93 \\
\hline Cameroon (3) & 52.67 & 0.495 & 15.7 & 1,319 & $-2,056.19$ & 16.08 & 4.23 \\
\hline Ethiopia (6) & 82.75 & 0.396 & 40.2 & 357 & $-6,355.71$ & 15.68 & 20 \\
\hline Ghana (3) & 47.45 & 0.558 & $<5$ & 1,570 & $-1,389.27$ & 33.40 & 36.48 \\
\hline Kenya (7) & 75.63 & 0.519 & 30.4 & 819 & $-5,738.56$ & 10.81 & 37.42 \\
\hline Mali (1) & 64.43 & 0.344 & 7.9 & 671 & na & 5.72 & 28.39 \\
\hline Nigeria (4) & 49.75 & 0.471 & 8.5 & 1,509 & $+16,031.18$ & 43.04 & 40.62 \\
\hline Tanzania (3) & 72.82 & 0.476 & 38.8 & 526 & $-3,548.42$ & 15.01 & 27.09 \\
\hline Togo (1) & 61.51 & 0.459 & 16.5 & 600 & -249.16 & 50.01 & 18.39 \\
\hline Uganda (8) & 84.02 & 0.456 & 34.6 & 558 & $-2,679.76$ & 44.79 & 25.58 \\
\hline Malawi (1) & 84.19 & 0.418 & 23.1 & 388 & +833.75 & 39.56 & 19.62 \\
\hline Mali (1) & 60.86 & 0.407 & $<5$ & 715 & na & 5.75 & 28.39 \\
\hline Mozambique & 68.57 & 0.327 & 39.2 & 536 & +1617.04 & 6.87 & 55.95 \\
\hline (1) & & & & & & & \\
\hline
\end{tabular}

Note: $\mathrm{na}=$ not available; HDI $=$ Human Development Index; GDP $=$ Gross Domestic Product. Source: Adapted from FAO (2013), World Bank (2013) and UNSD (2013).

Table 2 shows that the greatest portion of the population of African nations with active projects in partnership with Brazil is concentrated in rural areas. This suggests that these nations might be strongly dependent on agricultural activities. 
Furthermore, the Human Development Index (HDI) and the GDP per capita indicate that these nations have urgent problems in human and economic development. With regard to the Balance of Trade, the amount of area designated for agricultural activities, and the portion of undernourished population, Nigeria presents the best profile. On the other hand, Ethiopia, Tanzania, Kenya, Uganda, Mozambique, and Burkina Faso show poorer profiles, indicating that attention to issues related to agricultural development and food security is urgently needed. The evidence shows that with the exception of Ghana, which has undernourished population of less than 5\%, the African countries with which Brazil maintains cooperative relations through agribusiness projects have urgent problems regarding the size of their under nourished populations. Undernourishment is defined as a state lasting for at least one year in which the inability to acquire enough food persists, which is characterized by a level of food intake insufficient to meet dietary energy requirements (FAO, 2013). Therefore, this study argues that the projects developed in Africa in partnership with Brazil should attend more strongly to the problems related to the antecedents and consequences of undernourishment. Regarding to this issue, it is known that African countries face severe conditions of food insecurity, and an unsatisfactory progress toward reducing hunger and undernourishment levels (WFP, 2011; FAO, 2010). Indeed, Sub-Saharan Africa is responsible for 223 million undernourished people (FAO, 2013).

Benin has a diverse agricultural profile because of the change in climate from savannah-desert in the north to tropical rainforest in the south. In the north, agricultural activities focus on cotton and livestock. Thus, the most important food crops in the north are maize, sorghum, millet, and beans. On the other hand, in the south, agriculture is dominated by food crops, such as rice, cassava, yams, and beans. Palm oil, cashews, and peanuts are the main cash crops of this country (AGRIPROFOCUS, 2013; NEW AGRICULTURIST, 2013).

Burkina Faso is a landlocked country strongly dependent on cotton exports. Given this level of dependency on cotton exports, its farmers are extremely vulnerable to global price fluctuations. To fight this situation, the government has tried to diversify the country's agricultural base. However, previous efforts have met with unsatisfactory results (WORLD BANK, 2013). In addition to cotton, the main agricultural products of this country are peanuts, shea nuts, sesame, sorghum, millet, corn, rice, and livestock (NEW AGRICULTURIST, 2013). 
Cameroon is a prominent producer of cocoa. However, the ageing trees are an urgent problem for cocoa producers, who are discouraged from investing in replanting programs because of problems related to payment. Indeed, one of the main barriers to the economic progress of Cameroon's smallholder farmers is related to the lack of access to credit. Thus, in addition to cocoa, the main agricultural products of Cameroon are coffee, cotton, rubber, bananas, palm oil, grains, root starches, livestock, timber, rice, and maize (NEW AGRICULTURIST, 2013).

Ethiopia's economy is also strongly dependent on agriculture. This country has one of the largest populations in Africa. Agriculture, which is based on food crops and traditional livestock, is responsible for a great share of the country's GDP (DIAO; HAZELL; THURLOW, 2010). The main agricultural products are coffee, pulses, oilseeds, cereals, potatoes, sugarcane vegetables, and livestock is prominent. An interesting point is that Ethiopia's new Growth and Transformation Plan aims to improve the agribusiness sector through investments in commercial agriculture, which are focused on advanced farming technology, progressive irrigation techniques, high value crops, improved seeds, increased fertilizer consumption, and strategies for yielding multiple harvests each year (AGRI-PROFOCUS, 2013).

The agricultural growth in Mali is strongly attributed to rice and cotton. However, the production of dry cereal in Mali, which is the staple food of its population, is very low. Thus, access to food is inhibited by poverty and transportation costs (AGRI-PROFOCUS, 2013). In Malawi, agriculture is strongly focused on subsistence farming; thus, the food supply situation is precarious. This country is also highly vulnerable to natural disasters. However, in recent years, a government program that subsidizes fertilizers has helped to increase agricultural production, making Malawi a prominent exporter of food (BBC NEWS, 2013).

In Mozambique, agriculture is responsible for $31 \%$ of its GDP and $80 \%$ of employment. Major crops are cassava, corn, rice, tropical fruits, beef, and poultry. In addition, some crops, such as prawns, cashews, cotton, sugar, and copra are focused on the foreign market. Mozambique's agricultural profile is based on a great number of small proprieties. Production levels are low because of the use of traditional methods, few inputs, and lack of access to fertilizer, pesticides, manure, and animal traction. However, although the amount commercial agriculture is small it has some economic potential. 
The geographical conditions of Uganda, Ghana, and Kenya are favorable for agricultural activities. Ghana and Kenya also have coastal areas. Farming in Kenya is mainly carried out by smallholder producers. Because of the need for a structural reform in the agricultural sector of Kenya, the central theme of the government's Agricultural Sector Development Strategy is "farming as a business" (AGRI-PROFOCUS, 2013). The main agricultural products of Kenya are tea, coffee, maize, wheat, sugarcane, fruit, vegetables, dairy products, beef, pork, poultry, and eggs (NEW AGRICULTURIST, 2013).

In addition, Ghana and Uganda are part of a small group of African nations that have experienced high and stable agricultural growth (DIAO; HAZELL; THURLOW, 2010). Uganda has vast tracts of arable land, regular rainfall, and sizeable mineral deposits, which has led to robust economic growth in recent years (AGRIPROFOCUS, 2013). The main agricultural products of Uganda are coffee, tea, cotton, tobacco, cassava, potatoes, maize, millet, pulses, cut flowers, beef, goat milk, and poultry. The main agricultural products of Ghana are cocoa, rice, coffee, cassava, yam, groundnuts, maize, beans, bananas, and vegetables (NEW AGRICULTURIST, 2013).

In a few areas of the African continent, farmers have achieved significant agricultural production. In a survey of 3,000 small-scale farmers in eight subSaharan countries (i.e., Ethiopia, Malawi, Nigeria, Tanzania, Ghana, Kenya, Uganda, and Zambia), researchers found evidence of farms that have achieved agricultural yields that are greatly superior to the national average (DJURFELDT et al., 2005). The evidence also suggests that this intensification in performance is more often observed in some specific African regions and among specific categories of farmers (GABRE-MADHIN; HAGGBLADE, 2001; HAGGBLADE et al., 2002).

\section{CONCLUSIONS}

By examining the evidence of African regions regarding factors of agricultural production, this study found that Southern African has strong agricultural productivity and capital investments in agriculture. On the other hand, the agricultural realities of Middle, Eastern and Western Africa are more fragile in 
terms of fertilizer consumption, capital investments and, consequently, agricultural productivity. Therefore, this study suggests that Eastern and Western Africa are the weakest regions in terms of agricultural development. These findings are based on the evidence of active projects implemented in the partnership between Brazil and Africa. These projects are strongly concentrated in the two regions that need the greatest development of their agriculture activities.

Through the collaborative initiative of Brazil and Africa, projects focused on the innovative development of agricultural practices are underway in Africa in partnership with EMBRAPA. The currently active projects are concentrated in Eastern and Western Africa. This suggests that these regions are considered the most fragile in terms of investment and agricultural development. However, the active projects in these regions have differing goals, and they are weakly related. The active projects are related to agricultural productivity, food security, shared use of agricultural resources, environmental resources, and development of smallholders. However, an increased focus on basic aspects of agricultural activity, such as the efficient use of fertilizers, the use of advanced techniques of cultivation, and emancipatory social investments in the poorest African regions may have more immediate results and could make effective contributions to economic development in these regions. In addition, the enhancement of agricultural productivity in Africa and the consequent greater production of food and food security could be effectively promoted globally.

We argue that Brazil could aid agricultural development in Africa. Evidence confirms that increased investment in agricultural research leads to stronger agricultural development (ALSTON; NORTON; PARDEY, 1998; FAN et al., 2004). However, agricultural development needs to be associated with the development of supportive activities related to economic agents of the supply chains of smallscale farmers (e.g., input markets and suppliers, retailers, seasonal finance, and logistics infrastructure) (POULTON; KYDD; DORWARD, 2006). Thus, agricultural development needs to be associated with the development of a broad class of entrepreneurs (STAATZ; DEMBÉLÉ, 2007). Indeed, this complex development might be hampered by political instability and conflict threats. We argue that these issues need to be faced because their resolution is antecedent to strong agricultural development. Furthermore, this study supports the idea that initiatives focused on 
fighting undernourishment among the African population should be given priority. Assuming that undernourishment, especially during childhood, causes weakness in the cognitive and physiological activities of individuals, undernourishment can be seen as a significant antecedent of the low economic development in Africa. Therefore, it is necessary to concentrate efforts on solving the basic problem of undernourishment.

With regard to the limitations of this study, the analyzes do not consider animal and livestock productivity and the impact of agribusiness activities on economic development. In addition, the general evaluation presented in this study needs evidence of specific aspects of agricultural activities. It should be noted that initially the agricultural experience of Brazil could assist in developing an agricultural model that enhances African agricultural productivity and fosters its economic development. It also appears that, although the collaborative initiative between Brazil (EMBRAPA) and Africa is focused on the development of Eastern and Western Africa, currently active projects are scattered, and they focus on achieving different purposes. We suggest that such unfocused efforts on agricultural development in Africa will not enhance the development of elementary actions that aim at addressing urgent and emancipatory agricultural issues. Hence, we suggest that additional studies focused on the Eastern and Western regions of Africa should be developed in order to identify their agricultural limitations. In addition, future research could study social and environmental issues in relation to agricultural activities. Finally, a structured research agenda should be adopted in order to promote research on the development of the agricultural potential of Africa, especially in Eastern and Western Africa.

\section{REFERENCES}

AFRICA-BRAZIL.ORG. Africa-Brazil Agricultural Innovation Marketplace. 2013. Available at: < http://www.africa-brazil.org/> . Accessed: 03July 2012.

AGRI-PROFOCUS. Agri-ProFocus. 2013. Available at: < http://www.agri-profocus. $\mathrm{nl}>$. Accessed: 10 August 2013. 
BBC NEWS. Malawi Profile. 2013 Available at: < http://www.bbc.co.uk/news/worldafrica-13864367>. Accessed: 13October 2013.

BENJELLOUN, S. Food security prospects in the Maghreb. ARW Seminar on Environmental Challenges in the Mediterranean 2000-2050.Dordrecht Kluwer Academic Publisher. 2004.

BONELLI, R.; FONSECA, R. Ganhos de Produtividade e de Eficiência: Novos Resultados para a Economia Brasileira. Pesquisa e Planejamento Econômico, v. 28, n. 2, p. 273-314, 1998.

CHIKHURI, K. Impact of alternative agricultural trade liberalization strategies on food security in the Sub-Saharan Africa region. International Journal of Social Economics. v. 40, n. 3, p. 188-206, 2013. doi:10.1108/03068291311291491

CONNOLLY, A.J.; CONNOLLY, K.P.; LYON, M. A Seismic Change: Land Control in Africa. Is this a Wake-Up Call for Agribusiness? International Food and Agribusiness Management Review. v.15, n. 2, p. 171-177, 2012.

CONTINI, E.; MARTHA Jr., G.B. Brazilian agriculture, its productivity and change, Bertebos. Conference on Food security and the futures of farms: 2020 and toward 2050, Falkenberg: Royal Swedish Academy of Agriculture and Forestry, 2010.

DIAO, X.; HAZELL, P.; THURLOW, J. The Role of Agriculture in African Development. World Development. v. 38, n. 10, p. 1375-1383, 2010.

DIRIYE, M.; NUR, A.; KHALIF, A. Food Aid and the Challenge of Food Security in Africa. Development. v. 56, n. 3, p. 396-403, 2013. doi:10.1057/dev.2014.15

DJURFELDT, G.; HOLMEN, H.; JIRSTROM, M.; LARSSON, R. The African food crisis: Lessons from the Asian Green Revolution, Wallingford: CABI Publishing, 2005.

FAN, S.; ZHANG, X.; RAO, N. Public expenditure, growth and poverty reduction in rural Uganda. DSG discussion paper n. 4. Washington, DC: IFPRI, 2004. 
FAURÈS, J.M.; SANTINI, G. Water and the Rural Poor: Interventions for Improving Livelihoods in Sub-Saharan Africa. Rome: Food and Agricultural Organization of the United Nations, 2008.

FERREIRA, P. C.; MALLIAGROS, T. G. Impactos produtivos da infra-estrutura no Brasil - 1950-1995. Pesquisa e Planejamento Econômico. v. 28, n. 2, p. 315-338, 1998.

FOOD AND AGRICULTURE ORGANIZATION [FAO]. Food and Agriculture Organization of United Nations. 2015. Available at: < http://www.fao.org/home/ en/> Accessed 05 June 2015.

FOOD AND AGRICULTURE ORGANIZATION [FAO]. Progress towards millennium development goal 1: hunger Target. 2010. Available at: < http://www.fao.org/ hunger $>$. Accessed 18 May 2013.

GABRE-MADHIN, E. Z.; HAGGBLADE, S. Success in African agriculture: results of an expert survey. MSSD discussion paper 53. Washington, DC: IFPRI, 2001.

GODFRAY, H.C.J.; BEDDINGTON, J.R.; CRUTE, I.R.; HADDAD, L.; LAWRENCE, D.; MUIR, J.F.; PRETTY, J.; ROBINSON, S.; THOMAS, S.M.; TOULMIN, C. Food security: the challenge of feeding 9 billion people. Science. v. 327, n. 5967, p. 812-818, 2010.

GOMES, V.; PESSÔA, S. A; VELOSO, F. Evolução da Produtividade Total dos Fatores na Economia Brasileira: Uma Análise Comparativa. Pesquisa e Planejamento Econômico. v. 33, n. 3, p. 389-434, 2003.

HAGGBLADE, S. Modernizing African agribusiness: reflections for the future. Journal of Agribusiness in Developing and Emerging Economies. v. 1, n. 1, p. 10-30, 2011.

HAGGBLADE, S.; HAZELL, P.; REARDON, T. Strategies for stimulating growth of the rural nonfarm economy in developing countries. EPDT discussion paper $n$. 92. Washington, DC: IFPRI, 2002. 
INTERNATIONAL MONETARY FUND [IMF]. International Monetary Fund: data and statistics. 2012. Available at: < http://www.imf.org/external/index.htm>. Accessed: 20 June 2012.

INTERNATIONAL PEACE INSTITUTE [IPI]. The Global Observatory. 2013. Available at: <http://theglobalobservatory.org/indices/351-indices.html>. Accessed: 02 September 2013.

KITISSOU, M. Africa South of the Sahara 2008-2011: hunger as a factor in political instability. The Journal of Pan African Studies, v.6, n.7, p. 187-195, 2014.

MARTINELLI, L.A.; NAYLOR, R.; VITOUSEK, P.M.; MOUTINHO, P. Agriculture in Brazil: Impacts, costs, and opportunities for a sustainable future. Current Opinion in Environmental Sustainability, v. 2, n. 5-6, p. 431-438, 2010.

MWABU, G.; THORBECKE, E. Rural development, growth and poverty in Africa. Journal of African Economies, v. 13, n. 1, p. 16-65, 2004.

MWICHABE, S. The African Agrarian Ideology and the Food Security Challenge in Sub-Saharan Africa. Development, v. 56, n. 3, p. 412-420, 2013.

NEW AGRICULTURIST. New Agriculturist Country Profile. 2013. Available at: < http:// www.new-ag.info/en/country.php>. Accessed: 15 August 2013.

OLUKOSHI, A. Investing in Africa: The political economy of agricultural growth. Ids Bulletin-Institute of Development Studies, v. 36, n. 2, p. 13, 2005.

RODRIGUEZ, R. Agricultural development and trade liberalization. Agro-Food Chains and Networks for Development, v. 14, p. 29-39, 2006.

ROSEGRANT, M.W.; HAZELL, P. Transforming the rural Asian economy: the unfinished revolution, Hong Kong: Oxford University Press, 2000.

SEN, A. Poverty and Famines: an essay on entitlement and deprivation. Oxford: Clarendon Press, 1981. 
STAATZ, J.M.; DEMBÉLÉ, N.N. Background paper to the World Development report 2008: Agriculture for development in sub-Saharan Africa, 2007.

THE ECONOMIST. The miracle of the cerrado: Brazil has revolutionized its own farms. Can it do the same for others?. The Economist, August 26, 2010. Available at: $<$ http://www.economist.com/node/16886442> . Accessed: 05 June 2012.

TIMMER, C.P. Agriculture and pro-poor growth: what the literature says, draft paper. World Bank. Washington, DC: Agricultural and Rural Development Department, 2005.

UNITED NATIONS STATISTICS DIVISION [UNSD]. National Accounts Main Aggregates Database. 2012. Available at: < http:/unstats.un.org/unsd/snaama/ selbasicFast.asp > . Accessed: 05 June 2012.

VAN DIJK, H. Political Instability, Chronic Poverty and Food Production Systems in central Chad, Inside Poverty and Development in Africa, pp.119-143, 2008. Available at: < http://dx.doi.org/10.1163/ej.9789004158405.i-306.40> . Accessed: 05 June 2012.

VAN ROOYEN, J.; SIGWELE, H. Towards regional food security in southern Africa: a (new) policy framework for the agricultural sector. Food Policy, v. 23, n. 6, p. 491504, 1998.

WORLD BANK. Africa and Brazil Form Knowledge Partnership to Boost African Agriculture. The World Bank, November 02, 2010. Available at: <http://www. worldbank.org/en/news/2010/11/02/africa-brazil-form-knowledge-partnershipboost-african-agriculture > . Accessed 07 June 2012.

WORLD BANK. The World Bank Database. 2013. Available at: < http://www. worldbank.org/> . Accessed 22 May 2013.

WORLD FOOD PROGRAMME [WFP]. World Food Programme. 2011. Available at: $<$ http://http://www.wfp.org > . Accessed 22 May 2013. 
YAN, Y.; YI-XIANG, Z.; YI, L. The Policies for Promoting Agricultural Export in Brazil and the Reference Meaning to China. In: INTERNATIONAL CONFERENCE ON PUBLIC ADMINISTRATION, $\left(5^{\text {th }}\right)$, Proceedings of 2009 , v. 2, p. 919-923.

Recebido em: 27 de maio de 2015 Aceito em: 01 de julbo de 2015 